\title{
EFEKTIVITAS METODE NUMBERED HEADS TOGETHER TERHADAP PRESTASI BELAJAR MATEMATIKA
}

\author{
IYUS $^{1}$, PRADIPTA ANNURWANDA ${ }^{2}$, BERNADETA RITAWATI $^{3}$ \\ ${ }^{I}$ Mahasiswa Pendidikan Matematika, STKIP Pamane Talino, Kalimantan Barat \\ iyusbahatta00@gmail.com \\ ${ }_{2}^{2}$ Pendidikan Matematika, STKIP Pamane Talino, Kalimantan Barat \\ pradiptamaospati@gmail.com \\ ${ }^{3}$ Pendidikan Matematika, STKIP Pamane Talino, Kalimantan Barat \\ bernadetha.pamane@gmail.com
}

First Received: 16-04-2021; Accepted: 28-04-2021

\begin{abstract}
Abstrak
Tujuan dari penelitian ini adalah untuk mengetahui efektivitas metode Numbered Heads Together (NHT) dibandingkan metode konvensional terhadap prestasi belajar siswa kelas VIII SMP GKE Sidas tahun pelajaran 2019/2020 Kabupaten Landak. Penelitian ini adalah penelitian kuantitatif. Populasi dalam penelitian ini adalah siswa kelas VIII SMP GKE Sidas dan sampelnya adalah siswa kelas VIII A sebagai kelas eksperimen dan VIII B sebagai kelas kontrol. Teknik pengumpulan data adalah tes. Teknik analisis data menggunakan uji-t independent sample t-test. Hasil penelitian menunjukkan nilai rata-rata untuk kelas eksperimen adalah 60,37 dan untuk kelas kontrol adalah 55,57. Hasil uji-t dengan uji sampel independen diperoleh t_hitung 3,726 dan t_tabel 2,007 dengan taraf signifikan 5\%. Sehingga dapat disimpulkan bahwa Ha diterima dan Ho ditolak, sehingga terdapat perbedaan antara penggunaan metode Numbered Heads Together (NHT) dan metode konvensional terhadap prestasi belajar siswa kelas VIII SMP GKE Sidas tahun ajaran baru. gunakan tahun ajaran 2019/2020 Kabupaten Landak. Sehingga pembelajaran menggunakan metode Numbered Heads Together (NHT) lebih baik daripada metode konvensional.
\end{abstract}

Kata kunci: Prestasi belajar; Metode Numbered Heads Together; Metode Konvensional

\section{THE EFFECTIVENESS OF NUMBERED HEADS TOGETHER METHOD ON THE ACHIEVEMENT OF MATHEMATICS LEARNING}

\begin{abstract}
The purpose of the research is to determine the the use Numbered Heads Together (NHT) method more effective than conventional method on learning achievement for the eighth grade student of SMP GKE Sidas in the academic year of 2019/2020 Landak Regency. This research was quantitative research. The population of this research was the eighth grades of SMP GKE Sidas and the sample was students of VIII A as experiment class and VIII B as control class. The technique of collecting data was test. The technique
\end{abstract}


analyzing data was using t-test of independent sample t-test. The result of this research shows the average score for experiment class is 60,37 and for the control class is 55,57. The result of t-test with independent sample test gains $t$ _count of 3,726 and t table of 2,007 with significant level of $5 \%$. It can be concluded that $\mathrm{H}_{\mathrm{a}}$ is accepted and $\mathrm{H}_{\mathrm{o}}$ is rejected, so there is a difference between the use of Numbered Heads Together (NHT) method and conventional method on learning achievement or eighth grade student of SMP GKE Sidas in the use academic year 2019/2020 Landak Regency. So learning uses the Numbered Heads Together (NHT) method better than the conventional method.

Keywords: Learning achievement; Numbered Heads Together method; Conventional method

\section{PENDAHULUAN}

Pembelajaran matematika merupakan proses mengembangkan kreativitas berfikir siswa yang bertujuan untuk meningkatkan kemampuan berfikir siswa, dan dapat meningkatkan kemampuan mengonstruksi pengetahuan baru sebagai salah satu upaya meningkatkan penguasaan yang baik dalam pembelajaran matematika (Nuryanti \& Safitri, 2015). Berdasarkan observasi dengan guru mata pelajaran matematika diperoleh data bahwa SMP GKE Sidas diketahui prestasi belajar siswa yang rendah pada semester ganjil tahun pelajaran 2019/2012. Adapun penyebab rendahnya prestasi belajar siswa adalah sistem pembelajaran yang masih verbalisme. Dimana dalam pembelajaran ini siswa hanya sebagai penonton yang mendengar ceramah atau penjelasan dari guru, lalu mencatat materi yang disampaikan meskipun mereka tidak mengerti. Jadi metode pembelajaran yang digunakan Guru juga menentukan keberhasilan hasil pembelajaran.

Teknik pengajaran yang baik merupakan jawaban atas permasalahan tentang rendahnya prestasi belajar siswa. Oleh sebab itu, seorang guru perlu berupaya untuk memperbaiki mutu melalui proses pembelajaran yang baik. Salah satu usaha untuk memperbaiki mutu pembelajaran adalah dengan cara penggunaan metode Numbered Heads Together (NHT). NHT merupakan salah satu cara dari kelompok diskusi (Huda, 2013). Nuryanti \& Safitri (2015) menyatakan NHT atau penomoran di kepala merupakan sesuatu yang dirancang dapat mempengaruhi pola interaksi siswa. Menurut Lestari \& Mukhammad (2017), NHT merupakan jenis pembelajaran kooperatif sebagai alternatif terhadap struktur kelas tradisional.

Langkah - langkah pelaksanaan NHT menurut Huda (2013) adalah sebagai berikut: a) Siswa dibagi ke dalam beberapa kelompok-kelompok. b) siswa dalam kelompok diberi nomor. c) Guru memberi tugas pertanyaan kepada kelompok masing-masing untuk dikerjakan. d) Setiap kelompok mulai berdiskusi untuk menemukan jawaban yang dianggap paling tepat dan 
memastikan semua anggota kelompok mengetahui jawaban tersebut. e) Salah satu nomor secara acak dipanggil. f) Siswa dengan nomor yang dipanggil mempresentasikan jawaban dari hasil diskusi kelompok mereka.

Menurut pendapat Tirtaraharja dalam Supardi (2013) prestasi belajar adalah suatu kemampuan aktual yang bersifat terukur berupa keterampilan, sikap dan penguasaan ilmu pengetahuan yang peroleh peserta didik terhadap apa yang telah dipelajari di sekolah. Menurut Sultan (Supardi, 2013) tingkatan kemampuan maksimal yang dicapai setelah seseorang melalui proses belajar mengajar, biasanya diidentifikasi melalui evaluasi belajar dinamakan prestasi belajar. Singkatnya prestasi belajar merupakan tingkat penguasaan pengetahuan seorang siswa dalam melaksanakan kegiatan belajar (Annurwanda \& Friantini, 2019).

Keberhasilan peserta didik merupakan proses dari efektivitas belajar mengajar yang baik. Efektivitas dalam prestasi belajar adalah tingkat pencapaian kegiatan pelaksanaan tugas pokok semua orang dengan dukungan sumber daya yang dimiliki, dengan acuan indikator ideal yang direncanakan. Menurut Ensiklopedia Indonesia dalam Huda (2013), efektivitas merupakan sesuatu yang menunjukkan taraf ketercapaian suatu tujuan. Efektivitas dapat berupa dalam bentuk kuantitatif, yaitu merupakan membandingkan antara kondisi nyata dengan kondisi ideal. Berdasarkan uraian di atas, maka penelitian ini bertujuan mengetahui efektivitas metode NHT terhadap prestasi belajar Matematika siswa Kelas VIII SMP GKE Sidas Tahun Ajaran 2019/2020 Kabupaten Landak.

\section{METODE PENELITIAN}

Penelitian ini dilaksanakan di SMP GKE Sidas, semester genap tahun ajaran 2019/2020 Kecamatan Sengah Temila Kabupaten Landak. Penelitian ini menggunakan pendekatan kuantitatif. Menurut pendapat Sugiyono (2013) kuantitatif diartikan suatu metode penelitian yang berlandaskan pada filsafat positivisme, digunakan untuk meneliti pada populasi atau sampel tertentu, teknik pengambilan sampel pada umumnya dilakukan secara random, pengumpulan data menggunakan instrumen penelitian, analisis data bersifat kuantitatif atau statistik dengan tujuan untuk menguji hipotesis yang telah ditetapkan.

Populasi dalam penelitian ini adalah siswa kelas VIII SMP GKE Sidas tahun ajaran 2019/2020 yang berjumlah 53 siswa. Teknik pengambilan sampel yang digunakan yaitu cluster random sampling. Menurut Sugiyono (2013) cluster random sampling atau teknik sampling daerah digunakan untuk menentukan sampel bila objek yang akan diteliti atau sumber data yanag luas, misalnya penduduk dari satu negara, propinsi atau kabupaten. Untuk menentukan 
penduduk mana yang akan dijadikan sumber data, maka pengambilan sampelnya berdasarkan daerah populasi yang telah ditetapkan.

Metode pengumpulan data menggunakan teknik tes pilihan ganda dengan jumlah 25 butir soal. Uji instrumen penelitian meliputi uji validitas isi, reliabilitas, daya pembeda, dan indeks kesukaran soal. Pengujian validitas isi dilakukan dengan membandingkan antara isi instrumen dengan isi atau rancangan yang telah di tetapkan. Untuk isi dinilai dengan cara memberikan $(\sqrt{ })$ pada lembar validasi instrumen dan akan diisi oleh validator. Perhitungan reliabilitas instrumen teknik yang digunakan adalah rumus Alpha. Kriteria daya pembeda soal yang digunakan adalah soal dengan interprestasi yang diterima dengan baik sampai sangat baik, dengan kriteria daya pembeda $0,40<\mathrm{DP} \leq 0.70$ - $0,70<\mathrm{DP} \leq 1,00$. untuk mengetahui indeks kesukaran kriteria butir soal yang digunakan dalam penelitian ini adalah yang memiliki kriteria sedang.

Untuk melihat/menguji apakah data berdistribusi normal atau tidak dengan uji normalitas. Pengujian normalitas menggunakan Kolmogorov Smirnov dengan menggunakan SPSS 20. Homogenitas merupakan sebuah uji yang harus dilakukan untuk melihat kelas yang diteliti homogen atau tidak. Dalam penelitian ini, pengujian homogenitas menggunakan Homogeneity of variance test atau uji Levene Statistik dengan taraf signifikansi 5\%. Uji Hipotesis dilakukan untuk menguji kebenaran hipotesis yang telah diajukan. Pengujian hipotesis menggunakan uji Independent Sample Test atau uji t untuk dua sampel independen.

\section{HASIL DAN PEMBAHASAN}

Penelitian yang dilaksanakan di SMP GKE Sidas Kecamatan Sengah Temila Kabupaten Landak, khususnya pada kelas VIII. Penelitian ini dilaksanakan dengan menggunakan metode Numbered Heads Together (NHT). Data yang diperoleh adalah data prestasi belajar siswa pada mata pelajaran matematika kelas VIII A dan kelas VIII B pada pokok bahasan kubus dan balok. Jumlah siswa yang dilibatkan dalam penelitian ini adalah kelas VIII A berjumlah 27 dan kelas VIII B berjumlah 26 siswa.

Pengumpulan data dalam penelitian ini menggunakan metode tes yang berbentuk pilihan ganda. Metode tes yang digunakan untuk memperoleh data prestasi belajar siswa kelas VIIIA dan VIIIB setelah diberikan perlakuan yang berbeda. Sebelum soal diberikan kepada siswa, terlebih dahulu dilakukan uji validasi isi yaitu, meminta pertimbangan ahli untuk mengoreksi soal yang dibuat peneliti sebanyak 30 butir soal. Hal tersebut dilakukan untuk mengetahui apakah butiran soal yang digunakan sudah memenuhi kriteria yang ditentukan atau tidak. 
Soal diujicobakan pada kelas IX A untuk mengetahui reliabilitas, daya pembeda soal dan taraf kesukaran. Hasil validasi isi membuktikan bahwa 25 butir soal pilihan ganda dinyatakan valid. Selanjutnya uji reliabilitas dengan menggunakan rumus alpha, diperoleh hasil $r$ sebesar 0,805 yang artinya soal tersebut reliabel. Karena $r=0,805>0,6$ sesuai dengan kriteria yang ditentukan. Daya pembeda yang digunakan adalah soal dengan interpretasi yang diterima dengan baik sampai sangat baik, dengan kriteria daya pembeda $0,40<\mathrm{DP} \leq 0,70-0,70<\mathrm{DP}$ $\leq 1,00$ dengan jumlah yang memenuhi kriteria yaitu 25 butir soal. Perhitungan tingkat kesukaran soal dengan jumlah soal sebanyak 30 butir maka diketahui 5 soal adalah kategori sukar dengan rentang 0,00-0,30, selanjutnya 25 soal kategori sedang dengan rentang 0,30 0,70. Kriteria butir soal yang digunakan dalam penelitian ini adalah yang memiliki kriteria sedang.

Hasil analisis uji normalitas kelas VIII A didapat nilai Sig untuk metode pembelajaran Numbered Head Together (NHT) di kelas VIII A adalah 0,89 dan untuk metode pembelajaran konvensional di kelas VIII B memperoleh nilai Sig adalah 0,09. Dengan taraf signifikan sebesar 0,05, maka untuk kelas VIII A (metode Numbered Head Together (NHT)) 0,89>0,05 dan kelas VIII B (metode pembelajaran konvensional) 0,09 > 0,05. Dengan demikian dari hasil uji normalitas baik kelas VIII A (metode Numbered Head Together (NHT)) dan kelas VIII B (metode pembelajaran konvensional) berdistribusi normal. Adapun hasil uji normalitas data pada kelas eksperimen dan kelas kontrol dapat dilihat pada tabel berikut:

Tabel 1 Hasil uji normalitas kelas A dan kelas B

\begin{tabular}{|c|c|c|c|c|}
\hline & Kelas & $\begin{array}{c}\text { Kolmogoro } \\
\text { v-Smirnov } \\
\text { Statistic }\end{array}$ & Df & Sig. \\
\hline Prestasi & KelasA &, 156 & 27 & 0,89 \\
\hline $\begin{array}{c}\text { belajar } \\
\text { matematika }\end{array}$ & kelas B & ,200 & 26 & 0,09 \\
\hline
\end{tabular}

Uji homogenitas pada test of homogenity of variances dilakukan menggunakan uji levene dengan bantuan program SPSS 20. Setelah dilakukan dengan penghitungan dengan menggunakan bantuan program SPSS 20, diketahui nilai sig sebesar 0,564 pada taraf signifikan 5\% menunjukkan bahwa 0,564 > 0,05 maka $H_{a}$ diterima dan dapat disimpulkan bahwa kedua kelas antara kelas VIII A dan kelas VIII B dinyatakan homogen. Uji homogenitas selengkapnya dapat dilihat pada Tabel 2 berikut ini. 
Tabel 2 Uji homogenitas kelas A dan kelas B

\begin{tabular}{|c|c|c|c|}
\hline $\begin{array}{l}\text { Levene } \\
\text { Statistic }\end{array}$ & df1 & df 2 & Sig. \\
\hline .265 & 1 & 44 & .610 \\
\hline
\end{tabular}

Pengujian hipotesis dilakukan untuk menjawab rumusan masalah pada penelitian ini yakni apakah metode Numbered Heads Together (NHT) lebih efektif daripada metode pembelajaran konvensional terhadap prestasi belajar matematika siswa kelas VIII SMP GKE Sidas tahun ajaran 2019/2020 Kabupaten Landak?

Penelitian ini dianalisis dengan program SPSS 20 menggunakan metode independent sample test atau uji-t. Jika, $t_{\text {tabel }} \leq t_{\text {hitung }} \leq t_{\text {tabel }}$ maka Ho diterima dan jika, $t_{\text {hitung }}>t_{\text {tabel }}$ maka Ho ditolak. Adapun hasil dari pengujiannya dapat dilihat pada Tabel berikut:

Tabel 3 Hasil uji hipotesis

\begin{tabular}{|c|c|c|c|c|c|c|c|}
\hline \multirow[b]{3}{*}{$\begin{array}{l}\text { Prestasi } \\
\text { Belajar } \\
\text { Matematika }\end{array}$} & \multirow[b]{3}{*}{$\begin{array}{l}\text { Equal } \\
\text { Varians }\end{array}$} & \multicolumn{2}{|c|}{$\begin{array}{l}\text { Levene's } \\
\text { Test }\end{array}$} & \multicolumn{2}{|c|}{$\begin{array}{l}\text { t-test for Equality of } \\
\text { Means }\end{array}$} & \multirow{3}{*}{$\begin{array}{l}\text { Sig. } \\
(2- \\
\text { tailed) } \\
.004\end{array}$} & \multirow{3}{*}{$\begin{array}{l}\text { Mean } \\
4,793\end{array}$} \\
\hline & & & Sig. & $\mathrm{t}$ & $\mathrm{df}$ & & \\
\hline & & .337 & .564 & 3.726 & 51 & & \\
\hline
\end{tabular}

Dari hasil perhitungan $t$-test diatas, diperoleh nilai $t_{\text {hitung }}$ sebesar 3,726 dan $t_{\text {tabel }}$ sebesar 2,007. Dengan demikian, maka $t_{\text {hitung }}>t_{\text {tabel }}$ sehingga Ha diterima dan Ho ditolak. Berdasarkan hasil di atas, maka dapat disimpulkan bahwa prestasi belajar matematika siswa dengan menggunakan metode Numbered Head Together (NHT) lebih baik dibandingkan dengan siswa yang menggunakan metode pembelajaran konvensional. Sedangkan nilai rata pada kelas NHT 60,37 dan nilai rata-rata pada kelas metode konvensional yaitu 55,57. Untuk keterangan selengkapnya dapat dilihat pada Tabel 4.

Tabel 4 Nilai rata-rata kelas A dan kelas B

\begin{tabular}{|c|c|c|c|c|c|}
\hline & \multicolumn{3}{|c|}{ Group Statistics } & \multirow[b]{2}{*}{$\begin{array}{c}\text { Std. } \\
\text { Deviation }\end{array}$} & \multirow[b]{2}{*}{$\begin{array}{l}\text { Std. } \\
\text { Error } \\
\text { Mean }\end{array}$} \\
\hline & Kelas & $\mathrm{N}$ & Mean & & \\
\hline Prestasi & Kelas A & 27 & 60,370 & 9,60027 & 1,847 \\
\hline $\begin{array}{l}\text { Belajar } \\
\text { Matema } \\
\text { tika }\end{array}$ & Kelas B & 26 & 55,576 & 10,61385 & 2,081 \\
\hline
\end{tabular}




\section{SIMPULAN}

Berdasarkan hasil analisis dan pembahasan yang telah dilakukan sebelumnya, dapat disimpulkan bahwa: Metode Pembelajaran Kooperatif Numbered Heads Together (NHT) lebih efektif dari pada metode pembelajaran konvensional terhadap prestasi belajar matematika siswa SMP GKE Sidas Kabupaten Landak yang didasarkan pada hasil uji independent t test, karena diperoleh nilai $t_{\text {hitung }}$ sebesar 3,726 dan $t_{\text {tabel }}$ sebesar 2,007. Dengan demikian, maka $t_{\text {hitung }}>t_{\text {tabel }}$ sehingga Ha diterima dan Ho ditolak. Selanjutnya nilai rata-rata pada kelas yang menggunakan metode NHT sebesar 60,37, sedangkan pada kelas yang menggunakan metode metode konvensional sebesar 55,57 dengan demikian, metode NHT lebih efektif dibandingkan dengan siswa yang menggunakan metode konvensional terhadap prestasi belajar matematika siswa pada pokok bahasan kubus dan balok kelas VIII SMP GKE Sidas tahun ajaran 2019/2020 Kabupaten Landak.

\section{DAFTAR PUSTAKA}

Annurwanda, P. \& Friantini, R. N. (2019). Efektivitas Penerapan Metode Round Table dan Ekspositori terhadap Prestasi Belajar Matematika Ditinjau dari Kemampuan Awal. Riemann: Research of Mathematics and Mathematics Education. Vol. 1, No. 1, Oktober 2019, hal. 1-13.

Huda, Miftahul. 2013. Model-Model Pengajaran Dan Pembelajaran: Isu-Isu Metodis Dan Paradigmatis. Yogyakarta: Pustaka Belajar.

Lestari, K.E., dan Mukhammad Ridwan Yudhanegara, 2015. Penelitian Pendidikan Matematika. Bandung: PT Reflika Aditama.

Nuryati, Sri \& Safitri, Dian. 2015. Upaya Meningkatkan Motivasi Dan Prestasi Belajar Matematika Melalui Model Pembelajaran Kooperatif Tipe Numbered Heads Together (NHT) Siswa Kelas VIIIC SMP Muhamadiyah 1 Mingir. Jurnal derivat volume 2 No.1 (ISSN: 2407-3792) Halaman 24-32.

Supardi, U.S. 2013. Peran Berpikir Kreatif Dalam proses Pembelajaran Matematika. Jurnal Formatif 2: ISSN: 2088-351X Hal. 248-262. ISSN: 2302-2000

Sugiyono. 2011. Metode Penelitian Kuantitatif, Kualitatif, Dan R\&B. Bandung: Alfabeta, CV 